\title{
Monitoring of Verbal-Linguistic Development of Pre-school Children in Elementary School: RECEPTION project
}

\author{
Ines Krušelj-Vidas
}

ikvidas@gmail.com

Elementary School Matija Gubec Gornja Stubica, Croatia.

Keywords: primary school librarians, Croatia, advocating libraries, ERASMUS+ programme, pre-school pupils

\section{Abstract \\ The list of multiple tasks expected from a school librarian include a wide range of activities. Activity of crucial importance is advocating and argumentation how important is the development of basic literacy skills. The role of school librarians is unavoidable in this process.}

This presentation will show an example of school library practice and focus on the role of school librarian as designer, provider and researcher in the case study research at the school level. This research was done as an activity during international Erasmus + project called RECEPTION (Role of Early Childhood Education in positive Transition/Introduction Outcomes for New pupils).

\section{Context - General}

In the Republic of Croatia, the education system consists of the following: preschool education, elementary education, secondary education, higher education and adult education. Kindergartens have parental fees and are not obligatory, but preschool (one year before the school) is compulsory for all children at the age of six who do not attend kindergarten. Preschool programmes are free of charge. Eight-year elementary education in the Republic of Croatia is compulsory and free of charge for all children at the age of seven to fifteen. For students with multiple disabilities it lasts longer but not longer than the age of 21. Secondary education institutions are, depending on the type of educational programme, divided into high schools, vocational and artistic secondary schools. Universities, polytechnics and schools for professional higher education with all its constituents implement activities of higher education in the Republic of Croatia. (The Educational system in the Republic of Croatia, 2015.) Law in every school requires foundation of the library within the institution (Zakon o knjižnicama i knjižničnoj djelatnosti, 2019).

The four main domain of elementary school librarian work are (Standard za školske knjižnice, 2000):

1. organisation and developing of school library collection and everyday work with school library users (students and teachers)

2. educational work with students (development of basic literacy skills and information literacy skills, and all other projects and activities with students)

3. organisation of cultural and public activities for the whole school community 
4. miscellanea (for example improving the quality of school work as a member of school developing team).

Although law regulates the percentage of working hours for each domain, there is still a lot of freedom for each librarian to choose and plan activities that are more suitable for their own points of interests or their strong sides. Of course, all harmonized with school vision and mission and with full support of school leadership. That is why almost every school library in Croatia has its own "story to tell". What is more, during the work-time of one school librarian in the same school there are periods focused on certain activities that had been more intensive.

This presentation will provide an example of school library practice from Elementary school Matije Gupca Gornja Stubica, a small rural place $50 \mathrm{~km}$ far from Zagreb, the capital of Croatia.

\section{Case Study Research at School Level}

On the list of multiple tasks expected from a school librarian to do, one activity is crucial. This is the activity of advocating and argumentation of importance of basic literacy skills for all students, future employees of modern society. In this example of good practice, the school librarian was designer, provider and researcher in the case study research on the school level. This activity has an important goal - to use local research as a concrete argument to show the decision makers at the local level the need for additional work with pre-school children to develop their verbal-linguistic skills as important predictors of their future school achievement. This research was done as an activity during international Erasmus+ project called RECEPTION (Role of Early Childhood Education in positive Transition/Introduction Outcomes for New pupils). Erasmus + is the largest EU's programme to support education, training, youth and sport in Europe (What is Erasmus+?, 2017). Many opportunities are offered both to individuals and to organisations in order to develop and share knowledge and experience in different countries, members of EU. One of the most popular activities is the activity of cooperation and collaboration of several partners gathered around one interesting topic or problem.

As it is written on the official site of the project, RECEPTION is "a 3-year programme of research and development in early years of education. It is undertaken by 6 partner institutions integrating primary and pre-school education in Denmark, Croatia, Ireland, Iceland, Greece and Norway. It is focused on what we have termed the RECEPTION challenge: a trans-European need for primary schools to address the diversity of children's social and educational preparation for their entry to primary school.

We aim to investigate and disseminate successful attempts by our partner institutions to address the RECEPTION challenge within a wide range of demographic and socio-economic contexts and educational systems, in response to the needs of diverse and often disadvantaged children. Early years children across the European area are the ultimate beneficiaries of our project, but our immediate target groups are their teachers, school leaders, and associated professionals working within Early Years Education and Care (EHEC).”(Reception Project, 2016).

In order to contribute to RECEPTION project with original and "ready to use" method, the Croatian RECEPTION team described their local situation (for all those who will find some similarities) and find a problem, tested one possible method (which is easy to apply) and come out with a possible solution for the problem observed at beginning.

At the beginning of every school year 1st grade teachers of ES Matije Gupca Gornja Stubica embrace the challenge of working with children with extremely diverse level of readiness for formal education. These differences are based not only on children's individual abilities but mostly on the fact if children did or did

International Association of School Librarianship

https://iasl-online.org 
not attend kindergarten programme. The children who from the age of four attended kindergarten have undergone an intense programme of institutionalized support for the development of child's capacities. Those who did not attend kindergarten went through just one year of an obligatory preschool programme. There are many other factors which influence the readiness of a child to attend school and its future success.

Only $10 \%$ of the preschool population in Gornja Stubica attend kindergarten programme because there is no kindergarten in Gornja Stubica (the nearest one is in Donja Stubica). Most of the children are being looked after at home by grandparents or parents who are not employed. The majority of children from Gornja Stubica attend organized preschool programme in the ES Matije Gupca which is financed by local municipality, lasting 250 hours and it is organized for children at the age of six not attending any other form of preschool education.

In the Eurydice report Teaching Reading in Europe: Contexts, Policies and Practices (De Coster et al., 2011) it is specified that two specific factors affect students' achievement. Low educational level of parents and low socio-economic status of the family, as it is present in the majority of families in Gornja Stubica, causes low academic achievement of students. It is important to start as soon as possible to change that situation by influencing children's environment. Although the idea of establishing a kindergarten in Gornja Stubica has been around for several years, this data from Eurydice report is one more important argument to support initiative of establishing the kindergarten.

The admission staff of ES Matije Gupca Gornja Stubica have been monitoring preschool children over several years and the results show that some children come to preschool with poorly developed hygienic habits, some are unaccustomed to sharing toys or postponement of satisfying their own needs. Some of them do not know how to dress themselves or put on their shoes. Some have problems with separation from their parents. Solving these problems is the primary focus point in the preschool programme. The second step is the focus on the development of the skills necessary for starting education.

Particularly worrying is the information that in the past few years most of the teacher in ES Matije Gupca Gornja Stubica have noticed the increase of underdeveloped speech in pre-school population when they enrol into the first class. Acquiring competence of communicating in a mother tongue in regional situation is additionally burdened by the fact that in school the standard Croatian language is thought and for many children the mother tongue is local kajkavian idiom. The competence of oral expressing is an important pre reading skill. On the other hand, reading is the most important predictor of educational success and lifelong learning ability for each person.

One specific feature of ES Matije Gupca Gornja Stubica is that there is the pre-school educational institution within school building. That enables the employees of school (primarily the pedagogue and 1st grade teachers) to get to know some of future 1st graders even before the formal beginning of the 1st grade. It was decided to use this advantage to implement additional activities which would help preschool pupils move more smoothly into the area of formal education. In the school year 2017/2018 there were 37 pupils included in the pre-school programme. Twenty-eight of them attending the preschool programme in the main school building and it was decided to do the case study research with them. Although the sample was relatively small, the results are concrete and are planned to be used in future work of school in several different ways.

The main goal of case study was to do a research on efficiency of intensive reading stories aloud on the development of verbal-linguistic skills of preschool students in Elementary School Matije Gupca Gornja Stubica. The activity was intensively conducted by ten teachers included in RECEPTION project and it 
was an additional activity because a pre-school teacher sometimes reads stories aloud to children regardless of the project.

The research was designed so that the children who attend pre-school programme in main school building have been divided into two groups; one experimental where the activity of intensive reading stories aloud was done, and one control group where there was no such activity. The control group was needed so that the ordinary development of children without additional encouraging activities could be estimated.

Choosing stories for the reading aloud activity was a specially challenging task. The stories had to be age appropriate, with an interesting topic for children, "healing stories" - dealing with certain problem. An additional criterion was that the stories were available in English. In such a way other RECEPTION partners could use them as well, although in case study were used books in Croatian language. Two books written by Susan Perrow have been chosen: Healing Stories for Challenging Behaviour and Therapeutic Storytelling - 101 Healing Stories for Children (Perrow, 2010 and Perrow, 2013). All together twenty-two stories were chosen from these books for the reading aloud activity. During 3,5 months, every time the experimental group had classes, children listened to these stories as an additional activity. These stories are intended for children from the age of 3 to the age of 8 and basically they accompany the children in growing up, helping them in dealing with new and difficult situations which have, due to their intensity, caused inappropriate behaviour. Some of the topics appropriate for the preschool children are: changes and adaptation, fear from separation, obstruction, housekeeping and tidiness, disobedient children, scuffle, boredom, stubbornness, encouraging sharing and cooperation.

The question behind the activity was: What happens with the children during the activity? Will they have better results after the implementation of the activity?

To get the answer to the question stated above some statistical data about children's results in verbal-linguistic area had to be collected before the project started and after it finished. These data were collected both for experimental and control group by the teachers who were doing the reading aloud activity. The measuring was done twice: at the beginning and at the end of the research. Between these two measuring activities, in the experimental group the activity of intensive reading stories aloud had been done.

The estimation of the level of children's verbal-linguistic development or quantitative data were gathered using already designed methodology of measuring children's verbal linguistic skills designed by Dragan Lisica, an experienced speech therapist.

Although the method was originally intended for children who have speech impediments, it can easily be applied to all children. It is based on a picture book without text $A$ story to tell designed by Dick Bruna (Bruna, 2003) and on a booklet manual Path to the child's heart written by Dragan Lisica (Lisica, 2004) where all the necessary instructions for conducting the examination was found. Dragan Lisica states that the advantage of picture book as a means of examination lies in the fact that the examinee can develop its own observations, connect them and interpret them in a way which is similar to spontaneous speech and therefore the examinee's independence in structuring sentences and utterance can be studied. A child was offered a picture book „A story to tell“" by Dick Bruna and was told to tell the story based on the pictures. The following parameters were being measured: the length of the story, the number of used words and the accuracy of the story description. In the booklet manual there are: protocol for recording children's stories, table for assessing child's description of the story and protocol for comparing repeated measuring of verbal linguistic skills using $A$ story to tell picture book. There are also instructions how to prepare a

International Association of School Librarianship

https://iasl-online.org 
child for the activity of telling the story guided by pictures as well as the instructions for the examiners to be as neutral as possible without presumably encouraging and improving a child's vocabulary.

The length of the story is an important element in the estimation of the story quality and it was measured in minutes. It depends on many abilities that a child has; among the most important ones are: age, oral-linguistic maturity, the quality of attention and thinking, emotional maturity.

However, a story can be accurately told using fewer words. On the other side, a long story can lack precision and clarity. So it is for the best to take into account the average number of words combined with length and accuracy of the story telling.

The accuracy of the story description was measured by the number of points given according to the table in Dragan Lisica' manual (Lisica, 2004). The table for the estimation of the accuracy of the story description consists of three important criteria:

1. noticing and listing picture elements

2. connecting noticed and listed picture elements

3. enrichening of the utterance by using details

Obtained points were then compared with overall ranking and in such a way the level of verbal-linguistic development was determined:

\begin{tabular}{|c|c|c|c|c|}
\hline I & II & III & IV & V \\
\hline very weak & weak & good & very good & excellent \\
\hline
\end{tabular}

All the results have been analysed using Excel programme and here are the main findings about the quantitative data about verbal-linguistic achievements of the preschool pupils.

The average time of the first storytelling was a little bit more than nine minutes in both groups. The second storytelling in both groups was shorter than the first time. The difference in the length of the second storytelling between experimental and control group is negligible. This is understandable because the time difference between the two storytelling was only 3,5 months so children remembered the story well and in second measurement they needed less time in creating the narrative.

The average length of stories told by boys in experimental group was shorter than those told by girls. In the control group it was vice versa -boys' stories lasted longer than girls' stories. As it has already been mentioned to get a more accurate picture, the length of the story needs to be observed together with the data about the number of used words and the accuracy of the story description. 


\section{Comparison of the number of used words - experimental group}

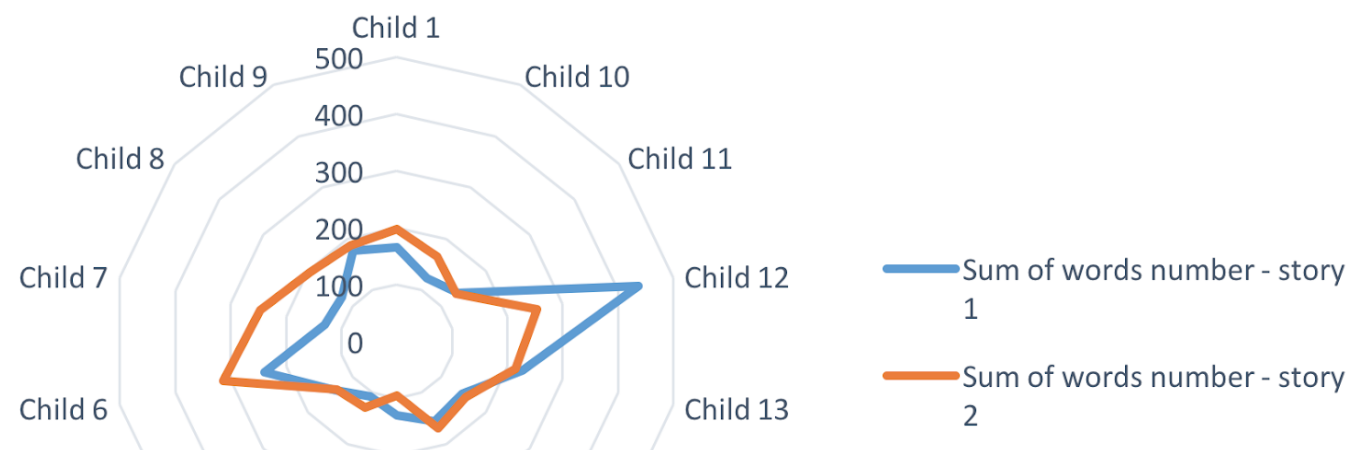

Child 5

Child 14

Child 4

Child 2

Child 3

Findings about the number of used words in a story: The overall number of words in the $1^{\text {st }}$ and $2^{\text {nd }}$ storytelling is 9098 . Children from experimental group used $15 \%$ more words than those from control group. If the $1^{\text {st }}$ and the $2^{\text {nd }}$ storytelling of experimental group is compared, the results show that in the $2^{\text {nd }}$ storytelling children used 6,4 \% more words. Boys increased the number of words for $12 \%$. Girls used approximately the same number of words (the decrease was only $0,86 \%$ ).

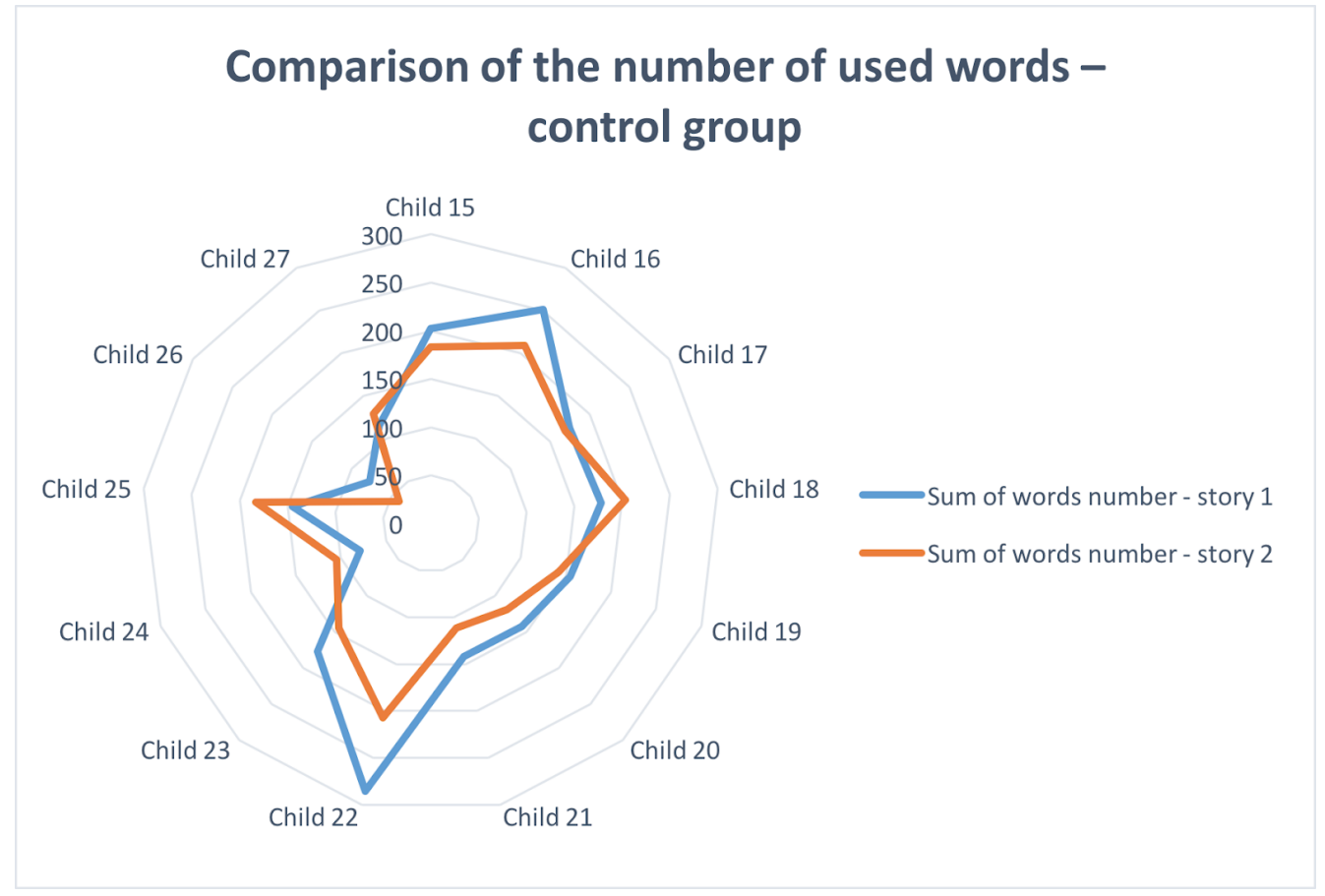

International Association of School Librarianship

https://iasl-online.org 
Based on the number of points given for the accuracy of the story description it can be noticed that one child from experimental group made progress from very good to excellent rank and two children made progress from good to very good rank. In control group two children also made progress from very good to excellent rank but two children dropped from weak to very weak rank and one child dropped from very good to good rank.

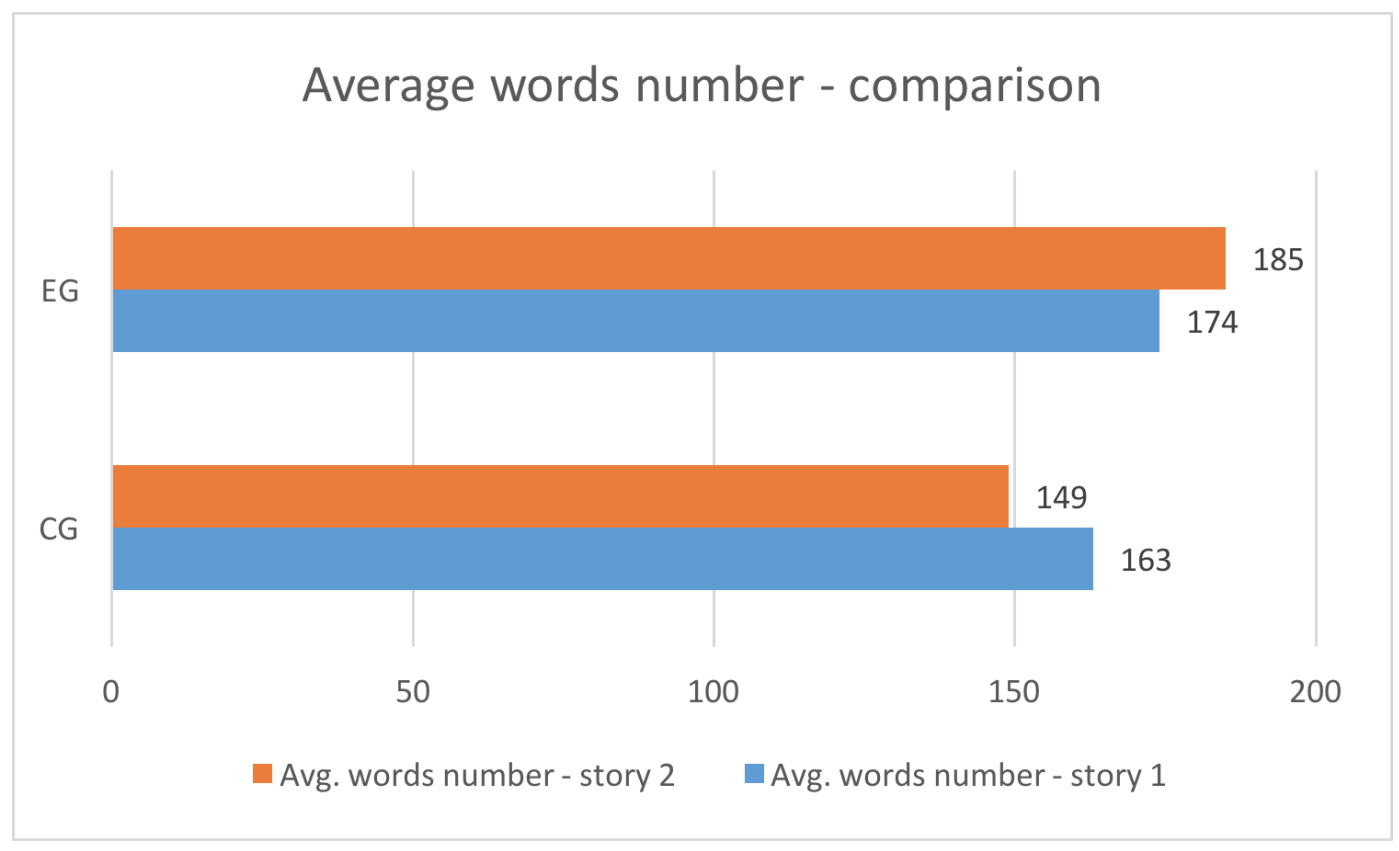

It is apparent that children from experimental group made progress and that the progress is uniformed.

In order to put the data obtained by this measuring activity into context, some interviews and questionnaires have also been done. Adult persons connected to the implementation of the activity have been interviewed. Pre-school teacher observed children during the reading aloud activity and was also interviewed at the beginning of the project and near its end. In the questionnaire parents are asked to share their own observations related to the degree of progress they noticed in their children. Observations and comments of the teachers providing the reading aloud activity were collected in the form of interview and questionnaire.

In such a way qualitative data on the implementation of planned activity have been gathered. Based on the results it can be concluded that all the interviewed people mentioned a positive effect of the reading aloud activity: parents of children from experimental group, teachers who have been implementing the activity and pre-school teacher as well.

Lastly, collected data have been analysed, quantitative indicators have been compared and connected to the statements which have been retrieved from the interviews.

Conclusions based on the comparison of experimental and control group results:

- in both groups the length of the 2 nd storytelling was shorter

- there are no significant differences connected to the gender of the children in relation to how long their stories lasted 
- children in experimental group used $15 \%$ more words than those in control group; in the 2nd storytelling children from the experimental group used $6,4 \%$ more words, and the number of words used by children in the control group was less by $18,1 \%$.

- $\quad$ as for the accuracy of the story, children from the experimental group have shown a consistent progress.

- crucial research indicator is also parents' educational level and families' social status. Seven parents from the experimental group have a university degree compared to 2 from the control group. Parents of children from the experimental group have a higher social status because only 3 mothers are unemployed while there are 6 unemployed parents in the control group.

Conclusions connected to the monitoring of the implementation of reading aloud activity:

- parents of children from the experimental group noticed positive reactions of their children to the implementation of the reading aloud activity

- teachers who did the activity point out that the children were attentive, interested and joyful

- pre-school teacher believes that the activity was encouraging and useful in developing children's concentration as well as communication with new, unfamiliar adults.

- $\quad$ special needs education teacher concludes that the analysis of the verbal-linguistic abilities could be used for planning a way how to help children whose results have not been so good.

Some of these conclusions can be used on a local level, related to our school and community, but some of them could be useful to partners in the RECEPTION project as well.

How important reading stories is, could never be emphasised enough - that's the conclusion that the 1st grade teachers can take out from this research. Exact data can substantiate how important it is to intensively work on the development of pre-reading skills and on the enrichening of a child's vocabulary (especially at the beginning of the 1st grade) - much more important than following the prescribed plans and programmes which have been designed at the national level for imaginary average population.

These arguments can also be used in working with parents to make them aware that today's school requirements are not the same as when they went to school, that it is important to efficiently work with their children at home which does not mean to take the role of a teacher but to spend quality time socializing with their children, talking to them and this conversation can also be prompted by reading a quality picture book.

This case study research can also be used as a concrete argument to show the decision makers at a local level the need for additional work with pre-school children. It can be done through an initiative for founding a kindergarten in the municipality of Gornja Stubica or to increase the number of hours of pre-school programme in Elementary School Matije Gupca Gornja Stubica. Including resources and school capacity in working with pre-school children should be additionally evaluated and adequate financial support should be asked for. All the above mentioned activities are supposed to be financed by local authority because according to the law of the Republic of Croatia local authorities are responsible for pre-school education.

When a research is being done, some unexpected activities can prove to be useful and beneficial. For example, it can be assumed that the instructions for reading aloud activity will be useful for teachers who have just started working. But parents can use them as well.

Most of the teachers who have taken part in doing this research have never before encountered therapeutically Susan Perrow's stories. All of them have noticed the positive effect these stories have on

International Association of School Librarianship

https://iasl-online.org 
children. The recommendation to use these therapeutic stories in everyday work can also be given to new teachers.

As far as research tools are concerned, there are certainly other instruments which can be used to measure pupils' achievements. But the tables which have been used, made by Dragan Lisica are easy to use and maybe this argument will be crucial for other teachers who decide to do the same kind of research. In Elementary school Matije Gupca Gornja Stubica it would definitely be useful to do the same research with pre-school children over a few more years to get more relevant data which could be used for different analysis. The fact that teachers themselves did the research is particularly valuable. In such a way they got the exact indicators of pupils' achievement so they do not have to rely only on their impressions or experience. They have become qualified to create their own database which can be used in their future work.

Analysing the measured data, the conclusion is that verbal-linguistic skills of children who have been exposed to the intensive activity of reading stories aloud have developed better than in children who have not been exposed to such an incentive. Susan Perrow's therapeutic stories that have been used, have proven to be encouraging and well accepted by children. It has been noted that the children have reacted extremely positively on the activity of reading stories aloud.

Why does this example of good practice work? The answer to this question lies in the fact that reading stories is important in the development of passive as well as active vocabulary in children. Although the enrichening of a child's vocabulary happens primarily at home, in cases of deprived family environment it is necessary to intensify the incentive in pre-school educational institutions (Čudina-Obradović, 2014). In the specific local context of Elementary School Matije Gupca Gornja Stubica these findings are extremely important because they provide some explanation as to why the results of some children have been on a rather low level.

\section{What was the role of school librarian in this project?}

The school librarian was the leader of the Croatian RECEPTION team and the coordinator of the project that included all management tasks to do considering the project (mostly organisational issues).

Nevertheless, when the Croatian RECEPTION team had chosen the topic of case study so closely connected with the main domain of librarian's work as a teacher, the role of librarian spread wider - to the designer, organizer and conductor of the case study research. When the team had made a framework of the research, librarian found the literature, provided the examples of Dick Bruna's and Dragan Lisica's books needed for the implementation of the initial and final measurements, found the appropriate books for reading aloud activity which needed to be both interesting to the pupils and reachable for all other RECEPTION partners - so, globally known and present, provided the examples of Susan Perrow books for reading aloud, found the instructions for teachers for successful reading aloud activity, summarized the results of measurements provided by the team members. As a person most involved in the design of case study, school librarian was also the author of that paper in cooperation with the English teacher, the member of the RECEPTION team, who did the translation to English language.

\section{Why is that important for the school library?}

In the small places where there is no public library, like it is in Gornja Stubica, school librarian has one more important role: he or she is presenting librarianship as the field, and each of his or her contribution to the promotion of any part of librarians' job is considered as advocating libraries in general.

To make this more clear it is enough to quote findings from the mentioned case study.

International Association of School Librarianship

https://iasl-online.org 
"Why have precisely these results been obtained? The answer lies in the fact that reading stories has an important role in enriching passive, as well as active vocabulary in children which is furthermore important in the development of phonemic consciousness in children. In the Croatian language phonemic consciousness is the basis for the reading ability which is in the 1st grade practised and adopted. Although the enrichening of a child's vocabulary primarily happens at home, in the cases of deprived family environment it is important to intensively work with these children in the institutions of pre-school education. In the local context of Elementary School Matije Gupca Gornja Stubica these findings are crucial because they explain why some children had weaker results.

Finally, although not less important, by reading stories readers and passionate readers are being brought up. Readers are persons who read fluently with comprehension which is an ability needed for further education and learning in general. A passionate reader is a person who enjoys reading and this ability affects and raises overall quality of life quality." (Krušelj-Vidas and Kontent, 2018).

\section{REFERENCES}

Bruna, Dick. (2003). Pričaj. Golden marketing. Zagreb.

Čudina-Obradović, Mira. (2014). Psihologija čitanja: od motivacije do razumijevanja: priručnik. Golden marketing-Tehnička knjiga: Učiteljski fakultet Sveučilišta u Zagrebu. Zagreb.

De Coster, Isabelle \& Baidak, Nathalie \& Motiejunaite, Akvile \& Noorani, Sogol. (2011). Teaching Reading in Europe: Contexts, Policies and Practices. Education, Audiovisual and Culture Executive Agency (EACEA P9 Eurydice) Web site. https://www.research gate.net/publication/303022099_Teaching_Reading_in_Europe_Contexts_Policies_and_ Practices (accessed Apr 9, 2018.).

Krušelj-Vidas, I.; Kontent, T. The Case Study Report - Croatia. (2018). Reception project Web site. https://www.dropbox.com/sh/12gs29yw2wiz2vm/AADSxs-m-eiqxu8L8ZXaIe2ua $/$ Croatia?dl=0\&preview $=$ Case + Srudy +-+ Croatia +-+ Full+Version.pdf\&subfolder_nav_tra cking=1 (accessed June 26, 2019.).

Lisica, Dragan. (2004). Put do dječjeg srca: priručnik za logopede, stručne suradnike i odgojitelje uz slikovnicu Dicka Brune „Pričaj!“‘. Golden marteking-Tehnička knjiga. Zagreb.

Perrow, Susan. (2010). Bajke i priče za laku noć. Ostvarenje. Zagreb.

Perrow, Susan. (2013). Iscjeljujuće priče II: 101 terapeutska priča za djecu. Ostvarenje. Zagreb. 
Reception Project (2016). Reception project Web site. https://receptionproject.eu/ (accessed June 26, 2019.).

Standard za školske knjižnice. (2000). Narodne novine: službeni list Republike Hrvatske. Web site. https://narodne-novine.nn.hr/clanci/sluzbeni/2000_03_34_698.html (accessed June 26, 2019.).

The Educational system in the Republic of Croatia. (2015). The Ministry of Science and Education of Republic of Croatia Web site. http://public.mzos.hr/Default.aspx?sec=2497 (accessed Oct 15, 2016).

What is Erasmus + ? (2017). European comission Erasmus + Web site. https://ec.europa.eu/prog rammes/erasmus-plus/about_en (accessed June 26, 2019.).

Zakon o knjižnicama i knjižničnoj djelatnosti. (2019). Narodne novine: službeni list Republike Hrvatske Web site. https://narodne-novine.nn.hr/clanci/sluzbeni/2019_02_17_356.html (accessed June 26, 2019.)

Biographical Note

Ines Krušelj-Vidas, school librarian promoted in advisor status, currently working in Elementary school Matija Gubec Gornja Stubica, Croatia, focused on developing and promotion of basic literacy skills among pupils; e-mail: ikvidas@gmail.com. 